\title{
Miyatrombicula (Miyacarus) kumadai n. sp. found on the Japanese dormouse, Glirulus japonicus (Prostigmata ; Trombiculidae)
}

\author{
Nobuhiro TAKADA* \\ Department of Parasitology, Hirosaki Unizersity School of Medicine, \\ Zaifu-cho, Hirosaki 036, Aomori Prefecture, Japan
}

(Received: June 2, 1978)

\begin{abstract}
Miyatrombicula kumadai n. sp. is described from the Japanese dormouse, Glirulus japonicus, in the northern part of Honshu, Japan. The new species resembles $M$. tokyoensis and $M$. jonesae, but is distinguished from them by the different characters of palpal, scutal and body setae, and host relationships.
\end{abstract}

A Miyatrombicula species was found on a Japanese dormouse, Glirulus japonicus, originally captured in a woods near Wakinosawa Village, Shimokita Peninsula, in the northern part of Japan, and reared by Prof. S. Hirata from January to March, 1978. The species resembles but different from $M$. tokyoensis (Kumada, 1954) and $M$. jonesae (Brennan, 1952).

\section{Miyatrombicula (Miyacarus) kumadai n. sp.}

(Japanese name: Kumada-tsutsugamushi)

Larva. Color in life yellow or faint orange. Ranges of length (BL) and width (BW) of partially engorged specimens $360-465$ by $211-$ $299 \mu \mathrm{m}$ smaller than $M$. tokyoensis. Eyes $2 / 2$.

Gnathosoma (Fig. 1-C). Characteristics similar to "cynos" group of Brennan (1952). Palpal setal formula B-B-BNb, palpogenual and palpotibial dorsal setae with fewer branches than palpofemoral seta, palpotibial ventral seta and galeal seta with 1-3 branches, palpotibial lateral seta nude (two specimens with a minute branch on one side). Blade of chelicera with tricuspid cap. Palpal claw trifurcate. Palpotarsus with 7 branched setae and a spur, subterminala lacking.

Scutum (Fig. 1-D and Table 1). Pentan-

* 高田伸弘：弘前大学医学部寄生虫学教室（干036 青森県弘前市在府町 5) gulate, obtuse posterior end forming an angle of approximately $100^{\circ}$. Sensillary bases about on level of posterolateral setae. Sensillae $44-53 \mu \mathrm{m}$ long, with comparatively long lateral branches on apical two-thirds, and spike-like barbs on basal one third. Other scutal setae typical for genus. Length of scutum (ASB + PSB) $42-53 \mu \mathrm{m}$ width (PW) 64-72 $\mu \mathrm{m}$ (range of 9-15 specimens), scutal shape resembles $M$. tokyoensis, but significantly smaller, especially close to size of M. jonesae.

Body setae (Fig. 1-A, B, G and Table 1). Dorsal setal formula 2, 9-12, 8-12, 7-8, 6-8, $5-7,2-4,2$ (ranged 44 to 53 in total), second and third rows irregular. Humeral seta well separated from second row, longer than other dorsal setae, with short spikes. Ventral surface with 2 pairs of sternal setae, 34-42 anteroanal setae, 15-21 posteroanal setae, and the latter similar to dorsal setae. In general, body setae fewer and shorter than those of $M$. tokyoensis.

Legs (Fig. 1-A, E and F). Each leg with 7 segments, tarsi terminate with a pair of claws and claw-like empodium. Posterior margins of all coxae concave and poorly chitinized. Coxa I and II with a single branched seta, coxa III with 3 setae as in $M$. tokyoensis and $M$. jonesae, the inner seta longest (one specimen with 2 setae on one side). Specialized setal formula as follows : 


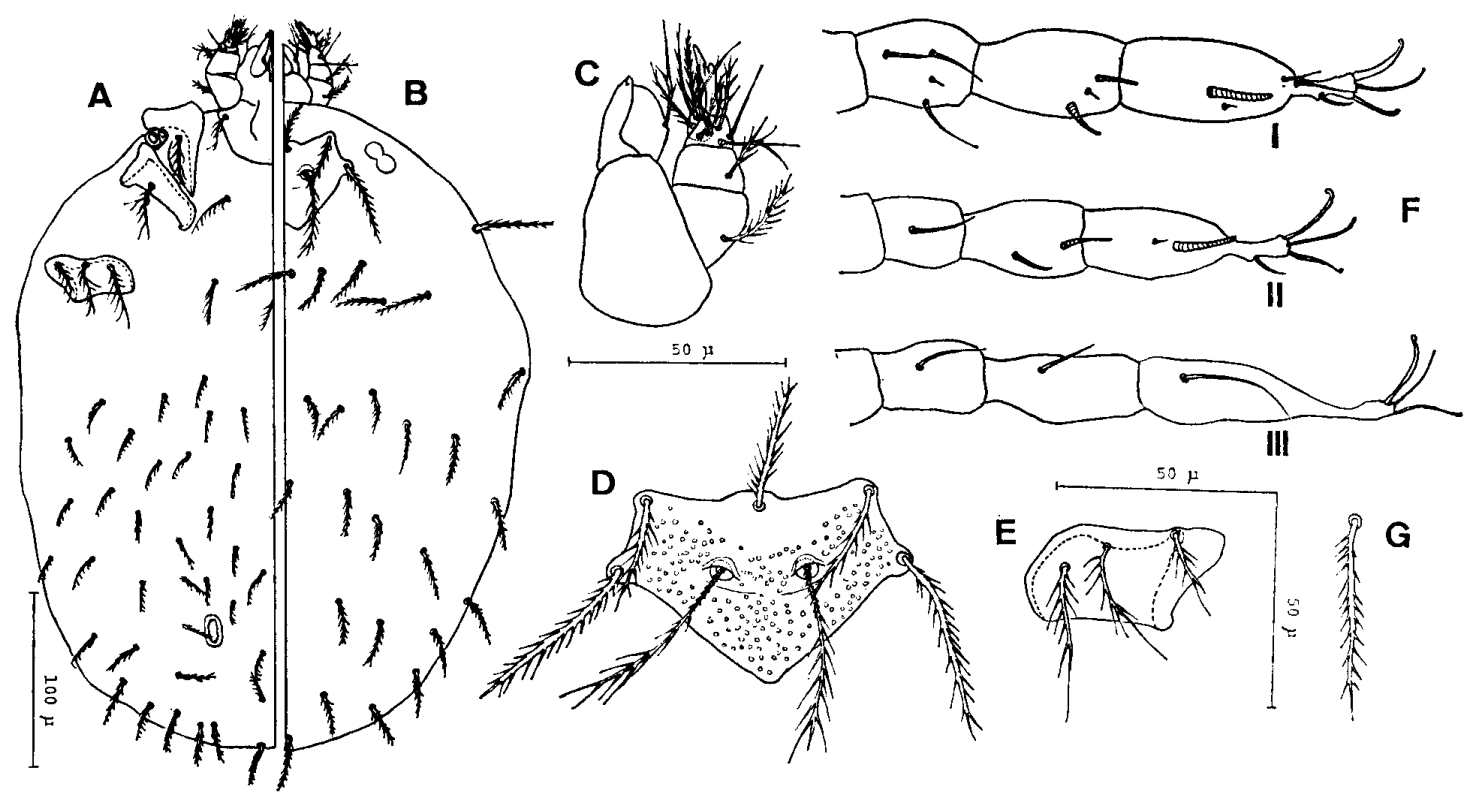

Fig. 1 Miyatrombicula (Miyacarus) kumadai n. sp., larva

(A) ventral and (B) dorsal view of engorged larva; (C) right half of gnathosoma;

(D) scutum; (E) coxa III ; (F) leg I, II and III with specialized setae ; (G) humeral seta

Table 1 Standard measurements of Miyatrombicula (Miyacarus) kumadai n. sp. (in microns)

\begin{tabular}{lccc}
\hline & Holotype & $\begin{array}{c}\text { Mean (range) of } \\
9-15 \text { specimens }\end{array}$ & M. tokyoensis* \\
\hline BL & 430 & $418(360-465)$ & - \\
BW & 281 & $250(211-299)$ & - \\
\hline AW & 52 & $53(48-56)$ & 61.05 \\
PW & 68 & $67(64-72)$ & 77.23 \\
ASB & 18 & $20(18-24)$ & 23.55 \\
PSB & 29 & $27(24-29)$ & 32.45 \\
SB & 20 & $20(18-24)$ & 21.77 \\
AP & 18 & $19(15-22)$ & 25.68 \\
AS & 23 & $23(20-26)$ & 28.32 \\
PS & 24 & $24(22-26)$ & 28.00 \\
pp-ss & 0 & $0.3(-3.5-+2.2)$ & +4.00 \\
am & 35 & $34(33-40)$ & 33.36 \\
al & 33 & $30(29-33)$ & 35.91 \\
pl & 45 & $44(40-48)$ & 51.91 \\
s & 50 & $48(44-53)$ & 60.32 \\
\hline hm & 46 & $44(40-46)$ & 52.27 \\
dsa & 39 & $36(33-40)$ & 38.09 \\
\hline DS & 48 & $49(44-53)$ & 56.22 \\
VS & 50 & $55(50-63)$ & 64.70 \\
\hline
\end{tabular}

* Mean of 11 type specimens (Kumada, 1954)

DS and VS: Total of the dorsal and ventral body setae, respectively 
Leg I : 3 genualae, 1 microgenuala ; 2 tibial spurs, 1 microtibiala; 1 tarsal spur, $1 \mathrm{mi}$ crotarsala, 1 subterminala, 1 parasubterminala, 1 pretarsala. Leg II : 1 genuala; 1 tibial spur, 1 tibiala; 1 tarsal spur, $1 \mathrm{mi}-$ crotarsala, 1 pretarsala. Leg III : 1 genuala ; 1 tibiala; 1 mastitarsala.

Type data. Fifteen specimens were collected from an adult Glirulus japonicus Schinz, 1845, on 20 March 1978 . The host was captured by Prof. S. Hirata in Wakinosawa, Shimokita-Gun, Aomori Prefecture, Japan, in January 1978. Holotype and 7 paratypes were deposited in the Department of Parasitology, Hirosaki University School of Medicine, Hirosaki, Japan. The species is named in honor of Prof. N. Kumada.

Diagnosis and discussion. The genus Miyatrombicula Sasa, Kawashima and Egashira, 1952, includes the following species in Japan : M. kochiensis (Sasa et al., 1952) in the southwest, M. esoensis (Sasa and Ogata, 1953) in the far north, $M$. tokyoensis (Kumada, 1954) in the middle, and M. okadai (Suzuki, 1976) in the far south. M. esoensis ( $=$ Trombicula reesi Allred, 1958) also occurs in North America (Brennan and Jones, 1959). Coxa III has two or more setae in the new species, M. tokyoensis and the "cynos" group. Hosts of cynos are mostly rodents (Brennan, 1952). Therefore, the author supports the view of Sasa and Ogata (1953) and Kumada (1954) that Japanese and North American species of the genus Miyatrombicula are related.

The new species is very close to $M$. tokyoensis. Both species are included in the subgenus Miyacarus Vercammen-Grandjean, 1968 , on the basis of their lacking a subterminala on palpotarsus. An examination of two paratypes of $M$. tokyoensis indicates that the new species differs in having a significantly smaller scutum with the posterior angle somewhat obtuse, sensillae with long branches and bases more or less level with the posterolateral setae, all palpal and galeal setae sparsely branched except palpotibial lateral seta which is usually nude, and body setae shorter and fewer in number. It is interesting that the type host of the new species is the Japanese dormouse (Myomorpha; Gliridae) and of M. tokyoensis the giant flying squirrel (Sciuromorpha; Sciuridae), both arboreal animals that may share the similar habitat. It should be noted that Tamiya (1962) recorded three larvae of $M$. tokyoensis from G. japonicus in Fukushima Pref., central Japan (at Oze?).

The new species is differentiated from the North American species, $M$. jonesae, by scutal and palpal characters, the smaller number of body setae, and the host. The type host of $M$. jonesae is Peromyscus sp. Cricetidae).

\section{ACKNOWLEDGEMENTS}

The author wishes to express his thanks to Prof. N. Kumada (Department of Medical Zoology, Nagoya University School of Medicine, Nagoya) for loan of paratypes of $M$. tokyoensis, and Prof. N. Wilson (Department of Biology, University of Northern Iowa, Cedar Falls, Iowa, U.S.A.) for literatures and critical reading of the manuscript. Thanks are also due to Prof. S. Hirata (Institute of Science Education, Faculty of Education, Hirosaki University, Hirosaki) for furnishing the host animal, and Prof. T. Yamaguchi (Director of my Department) for his constant guidance.

\section{REFERENCES}

Brennan, J. M. (1952) : Trombicula cynos Ewing, 1937, and three related new species (Acarina: Trombiculidae). Wasmann J. Biol., $10: 55^{-65}$.

Brennan, J. M. and E. K. Jones (1959): Keys to the chiggers of North America with synonymic notes and descriptions of two new genera (Acarina: Trombiculidae). Ann. Entomol. Soc. Am, $52: 7-16$.

Kumada, N. (1954): A new trombiculid mite of the genus Trombicula, subgenus Miyatrombicula from Tokyo, Japan (Acarina: Trombiculidae). Bull. Tokyo Med. Dent. Univ., 1 : 93-98.

Sasa, M., K. Kawashima and M. Egashira (1952) : Studies on Tsutsugamushi, Part 25. Trombicula (Miyatrombicula) kochiensis, n. subg., n. sp., from western Japan. Tokyo Iji Shinshi, 69: 337-338 (in Japanese).

Sasa, M. and K. Ogata (1953): Studies on Tsutsugamushi, Part 53. A new species of the subgenus Miyatrombicula, with notes on the trombiculid mites of Hokkaido. Jap. J. Exp. Med., 23 : 333-346.

Suzuki, H. (1976) : Reports of medico-zoological investigations in the Nansei Islands. Part V. 
Six new species of chiggers from the Amami Island (Prostigmata; Trombiculidae). Jap. J. Sanit. Zool., 27 : 271-282 (in Japanese).

Tamiya, T. (1962): Recent advances in studies of tsutsugamushi disease in Japan, $309 \mathrm{pp}$., Medical Culture Inc., Tokyo.

Vercammen-Grandjean, P. H. (1968) : The chigger mite of the Far East. 135 pp., U. S. Army Med. Res. and Devel. Comm., Washington, D. C.

\section{摘 要}

ヤマネに見いだされたツツガムシの 1 新種

Miyatrombicula kumadai の記載

青森県下北半島の山林で捕獲されたヤマネから，ツツ ガムシの 1 新種 Miyatrombicula (Miyacarus) kumadai クマダッツガムシを記載する. 本種は M. tokyoensis (Kumada)および北米産の M. jonesae (Brennan) に似 るが，背甲板が小さく，感覚毛は後側毛とほぼ同一線上 にあって，その側枝が長いこと，触肢の毛やガレア毛の 側枝は少なく触肢脛節側縁毛が通常単条であること， 胴部の背腹毛はやや短かくて数が少ないことによって 容易に区別でき，また宿主も異なる．本種名は， $M$. tokyoensis の副模式標本参照に際して御配慮いただいた 熊田信夫教授に奉献したものである。 